\title{
Characterization of Botryosphaeriaceae from plantation- grown Eucalyptus species in South China
}

\author{
S. F. Chen ${ }^{1,2}$, D. Pavlic ${ }^{1}$, J. Roux ${ }^{1}$, B. Slippers ${ }^{3}$, Y. J. Xie ${ }^{2}$, M. J. Wingfield ${ }^{1}$ and X. D. Zhou ${ }^{1,2}$
}

(1) Department of Microbiology and Plant Pathology, Forestry and Agricultural Biotechnology Institute (FABI), University of Pretoria, Pretoria 0002, South Africa.

(2) China Eucalypt Research Centre (CERC), Chinese Academy of Forestry (CAF), ZhanJiang 524022, GuangDong Province, China.

(3) Department of Genetics, Forestry and Agricultural Biotechnology Institute (FABI), University of Pretoria, Pretoria 0002, South Africa.

X. D. Zhou

Email: cerc.zhou@gmail.com, xu.zhou@fabi.up.ac.za

\begin{abstract}
The Botryosphaeriaceae is a species-rich family that includes pathogens of a wide variety of trees, including Eucalyptus species. Symptoms typical of infection by the Botryosphaeriaceae have recently been observed in Eucalyptus plantations in South China. The aim of this study was to identify the Botryosphaeriaceae associated with these symptoms. Isolates were collected from branch cankers and senescent twigs of different Eucalyptus spp. All isolates resembling Botryosphaeriaceae were separated into groups based on conidial morphology. Initial identifications were made using PCR-RFLP fingerprinting, by digesting the ITS region of the rDNA operon with the restriction enzymes $C f o \mathrm{I}$ and $K s p \mathrm{I}$. Furthermore, to distinguish isolates in the Neofusicoccum parvum/N. ribis complex, a locus (BotF15) previously shown to define these species, was amplified and restricted with $C f o I$. Selected isolates were then identified using comparisons of DNA sequence data for the ITS rDNA and translation elongation factor 1-alpha (TEF-1 $\alpha$ ) gene regions. Based on anamorph morphology and DNA sequence comparisons, five species were identified: Lasiodiplodia pseudotheobromae, L. theobromae, Neofusicoccum parvum, $N$. ribis sensu lato and one undescribed taxon, for which the name Fusicoccum fabicercianum sp. nov. is provided. Isolates of all species gave rise to lesions on the stems of an E. grandis clone in a glasshouse inoculation trial and on the stems of five Eucalyptus genotypes inoculated in the field, where L. pseudotheobromae and $L$. theobromae were most pathogenic. The five Eucalyptus genotypes differed in their susceptibility to the Botryosphaeriaceae species suggesting that breeding and selection offers opportunity for disease avoidance in the future.
\end{abstract}

\section{Introduction}

The Botryosphaeriaceae (Botryosphaeriales, Ascomycetes) is a family of fungi that have a cosmopolitan distribution and occur on a wide range of monocotyledonous, dicotyledonous and gymnosperm hosts (Barr, 1987; Crous et al., 2006; Slippers \& Wingfield, 2007). These fungi are generally regarded as weak, opportunistic pathogens that cause disease symptoms on plants exposed to stressful environmental conditions such as those associated with drought, frost, hail and damage caused by other pathogens and pests (Smith et al., 1994; Slippers \& Wingfield, 2007). It has also been shown that the Botryosphaeriaceae occur in symptomless tissues as endophytes and latent pathogens on a variety of trees, including Eucalyptus spp. (Smith et al., 1996; Mohali et al., 2007; 
Pavlic et al., 2007; Slippers \& Wingfield, 2007; Slippers et al., 2009). These fungi can cause different symptoms on Eucalyptus, but are typically associated with cankers and die-back followed by kino exudation and in severe cases tree death (Smith et al., 1996; Slippers \& Wingfield, 2007).

Species of the Botryosphaeriaceae are considered to be a significant threat to the production and sustainability of plantations of Eucalyptus spp., where they are grown as non-native crops (Smith et al., 1994, 2001; Slippers et al., 2004b, 2009; Mohali et al., 2009; Rodas et al., 2009). At least 23 species of Botryosphaeriaceae have been associated with Eucalyptus spp. in commercially grown plantations worldwide (Slippers et al., 2009). Some of these species, such as Botryosphaeria dothidea and Neofusicoccum ribis were the most commonly reported species from Eucalyptus spp. in the past (Slippers et al., 2009). However, the application of DNA-based molecular tools for identification of species in the Botryosphaeriaceae has shown that these two species are rare on Eucalyptus spp. Furthermore, a large number of new or cryptic sister species have been identified on Eucalyptus spp., mostly in the genera Neofusicoccum, Pseudofusicoccum and Lasiodiplodia (Slippers et al., 2009).

Eucalyptus plantations are of increasing importance in China where they provide the country with structural timber and pulp products such as paper. Approximately 2.6 million hectares of Eucalyptus plantations have been established in China to meet the needs of the country, especially for the rapidly growing pulp industry (Xie, 2006; Iglesias-Trabad \& Wilstermann, 2008). Eucalyptus trees are thus important in China, both for the development of the economy and protection of native ecosystems that have been strictly protected from logging since the beginning of the 21 st century.

Similar to the situation in other countries (Wingfield et al., 2008), Eucalyptus plantations in China are threatened by various pests and diseases (Zhou et al., 2008). However, limited research has been conducted on Eucalyptus diseases in this country. A recent survey of Eucalyptus plantations in South China reported a number of fungal pathogens, including species within the Botryosphaeriaceae (Zhou et al., 2008). The aims of the current study were to identify the Botryosphaeriaceae occurring on Eucalyptus spp. in the FuJian, GuangXi and HaiNan Provinces in South China, using PCR-RFLP fingerprinting analysis, DNA sequence comparisons and morphology of the anamorph stages. Furthermore, the pathogenicity of these fungi was tested on Eucalyptus genotypes in glasshouse and field trials.

\section{Materials and methods}

\section{Isolates}

Isolates used in this study were collected from different Eucalyptus clones/species in plantations in FuJian, GuangXi and HaiNan during the period of 2006 and 2007. Isolations were made from diseased branches, and from pycnidia formed on senescing branches following the protocols described by Pavlic et al. (2007, 2008). Cultures were maintained on 2\% malt extract agar (MEA) (20 g malt extract, $15 \mathrm{~g}$ agar, $1 \mathrm{~L}$ water; Biolab) at $25^{\circ} \mathrm{C}$ under near-fluorescent light and stored at $5^{\circ} \mathrm{C}$. To induce sporulation of cultures, isolates were transferred to $2 \%$ water agar (WA) ( $20 \mathrm{~g}$ agar, $1 \mathrm{~L}$ water; Biolab) with sterilized pine needles placed on the agar surface and incubated at $25^{\circ} \mathrm{C}$ for 10-14 days until fruiting structures appeared on the surface of the pine needles.

Conidial masses from fruiting structures were spread on the surface of WA in sterile drops of water. Single germinating conidia were isolated after $4-12 \mathrm{~h}$, and transferred to clean $2 \%$ MEA plates. All the single-spore cultures are maintained in the Culture Collection (CMW) of the Forestry and Agricultural Biotechnology Institute (FABI), University of Pretoria, South Africa and the China Eucalypt Research Centre (CERC), Chinese Academy of Forestry (CAF), China. 


\section{DNA extraction and PCR amplification}

For DNA extraction, single-conidial cultures were grown on $2 \%$ MEA for $7-10$ days at $25^{\circ} \mathrm{C}$ in the dark. Mycelium used for DNA extraction was scraped directly from the medium using a sterile scalpel, and transferred to $1.5 \mathrm{~mL}$ Eppendorf tubes. DNA was extracted following a modified DNA extraction method (Raeder \& Broda, 1985; Smith et al., 2001). The DNA pellets were re-suspended in $50 \mu \mathrm{L}$ sterile SABAX water. RNAse $\left(1 \mathrm{mg} \mathrm{mL}^{-1}\right)$ was added to DNA suspensions and incubated overnight at $37^{\circ} \mathrm{C}$ for RNA degradation. DNA was separated by electrophoresis on a $1 \%$ agarose gel, stained with ethidium bromide and visualized under ultraviolet (UV) light.

The internal transcribed spacer (ITS) regions, ITS1 and ITS2, and the 5.8S gene of the ribosomal DNA (rDNA) operon, were amplified using the primers ITS1 (5'-TCCGTAGGTGAACCTGCGG$3^{\prime}$ ) and ITS4 (5'-TCCTCCGCTTATTGATATGC-3') (White et al., 1990). Part of the translation elongation factor 1-alpha (TEF-1 $\alpha$ ) gene was amplified using the primers EF1-728F (5'CATCGAGAAGTTCGAGAAGG-3') and EF1-986R (5'-TACTTGAAGGAACCCTTACC-3') (Carbone et al., 1999). The PCR reactions were performed following the PCR protocol described in Slippers et al. (2004a). In the case of isolates that were difficult to amplify using primers EF1-728F and EF1-986R, the primers EF1F (5'-TGCGGTGGTATCGACAAGCGT-3') and EF2R (5'AGCATGTTGTCGCCGTTGAAG-3') (Jacobs et al., 2004) were used. The PCR amplicons were viewed on a $1 \%$ agarose gel, stained with ethidium bromide and visualized under UV light. The fragment sizes were estimated against a standard $100 \mathrm{bp}$ molecular weight marker (Roche Molecular Biochemicals). The PCR products were cleaned using 6\% Sephadex G-50 columns (Sigma-Aldrich).

\section{PCR-RFLP analysis}

A PCR-RFLP fingerprinting technique was applied to identify groups among the collected isolates and to select representative isolates for sequencing. The ITS rDNA locus was amplified from all the isolates using primers ITS1 and ITS4 and amplicons were digested with the restriction enzymes (RE) $C f o I$ and KspI (Roche Diagnostics). Isolates identified as representing the Neofusicoccum parvum/N. ribis complex were further separated by PCR-RFLP analysis of the amplicons obtained using primers BotF15 and BotF16 (Slippers et al., 2004b) and digested with CfoI. The RFLP reaction mixtures consisted of $20 \mu \mathrm{L}$ PCR products, $0.30 \mu \mathrm{L} \mathrm{RE}$ and $2.5 \mu \mathrm{L}$ matching enzyme buffers. The reaction mixtures were incubated for $18 \mathrm{~h}$ at $37^{\circ} \mathrm{C}$. The resulting restriction fragments were separated on $2 \%$ agarose gels, stained with ethidium bromide and visualized under UV light. A standard $100 \mathrm{bp}$ molecular marker was used to estimate the fragment sizes. The banding patterns were compared with those previously published (Slippers et al., 2004b).

\section{DNA sequencing and analysis}

Representative isolates from all groups identified based on PCR-RFLP analysis were sequenced (Table 1). To determine their identities, ITS and TEF-1 $\alpha$ sequences of known Botryosphaeriaceae species were obtained from GenBank and included in the analysis (Table 1). The PCR products were sequenced in both directions using the same primers that were used for PCR reactions, and were purified using 6\% Sephadex G-50 columns. Sequence reactions were run on an ABI PRISM $3100^{\mathrm{TM}}$ autosequencer (Perkin-Elmer Applied Biosystems).

Nucleotide sequences were analysed using mega4 software (Tamura et al., 2007). Sequence alignments were conducted online using mafft version 5.667 (Katoh et al., 2002) with the iterative refinement method (FFT-NS-i settings) and adjusted manually. Gaps were treated as a fifth character and all characters were unordered and of equal weight. A partition homogeneity test (PHT) was used to determine the congruence of the ITS and TEF-1 $\alpha$ datasets (Farris et al., 1995; 
Huelsenbeck et al., 1996). After an outcome indicating congruence between the datasets, phylogenetic analyses of the combined datasets were done in paup (Phylogenetic Analysis Using Parsimony) version 4.0b10 (Swofford, 2002). Most parsimonious trees were found using the heuristic search function with 1000 random addition replicates and tree bisection and reconstruction (TBR) as branch swapping algorithm. Maxtrees were unlimited, branches of zero length were collapsed, and all most parsimonious trees were saved. A bootstrap analysis (1000 replicates) was done to determine the confidence levels of the tree-branching points (Felsenstein, 1985). The sequence of Guignardia philoprina from GenBank was used as the outgroup taxon (Table 1).

Table 1. Isolates considered in the phylogenetic study and pathogenicity tests.

\begin{tabular}{|c|c|c|c|c|c|c|c|c|c|c|}
\hline aclats Now & Cotar Nos & deray & & Hor & & Location & & Colectar & GeatrinTS & GarearkTeF sa \\
\hline $\operatorname{cas} 119047$ & & Satyosphoarb cartbls & & Vosdinim arynbasm & & Now boraer USA & & P.V Oudanans & Dosendis & Exonzso \\
\hline ATCC 22927 & & 8. cantils & & Vaconim 20 & & North Cancina Usa & & F.O Mitreland & Doonaly & EF14931 \\
\hline CMN 780 & & Sotpospreare datidso & & Fraethes arcalsig & & Mareza smiegrand & & A sloows & AYraseat? & Ay290506 \\
\hline CMN 8000 & & 8. dotrubaa & & Punusap. & & Crodraso swererland & & B. sicosen & AY23ES4? & AYzatas \\
\hline CMN 13425 & $\cos 1174+6$ & Botposproave maneno & & Acacia marpium & & Porbousas azate Vere & wela & 5. Marsi & EF 118246 & (6.) 134990 \\
\hline $\operatorname{CrN} 13420$ & CBS 117466 & 8. mamano & & Eucdppus fytord & & Cqudes abta Voneu & & S Mans! & EF11848 8 & Q.) 2400 \\
\hline CAN 22674 & $\cos 24054$ & Fusioascum stownare & & Provospus agdankis & & Soun Atros & & I MoN S I Fa. & FNe8RA3 & F)esed 55 \\
\hline Cun 2262 & $\operatorname{cBs} 24966$ & F. atoricare & & P argabansis & & Scut Anca & & J MEN S J ROW & F.8989,76 & F) \\
\hline CMN 2616 & c8s vaces & Fusionceum r amasum & & E comotalares & & BollGoges Autralia & & T. Rugoss & Eu1 $4 \$ 065$ & BUYACOO \\
\hline CMN $24700^{\circ \prime}$ & $\operatorname{CBS} 127187$ & Fusiocosum fobicovcianum & & E grondstyend & & Quangki chins & & $M+1$ Wropkid $\Delta \times D$ zhou & HCas?206 & Hosa2211 \\
\hline CNW $2 \times 0 \mathrm{H}^{2}$ & & F. fablowisianum & & 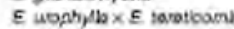 & clone & HoNan Crisa & & M.d Wrofkid $8 \times D$ Zha & Hodas D6 & 1030220 \\
\hline CNN $2 \mathrm{NOO}^{41 \mathrm{i}}$ & $\operatorname{CBS}+2719$ & F tablowcianum & & Eucd,pous so & & Fulan Chins & & M.J Wrofield & Hoces:27 & $\operatorname{tose2} 24$ \\
\hline CNW $27106^{\circ}$ & & F tabioncianum & & sucdneus so & & Fulan cting & & Md Mrofend & $\because 033200$ & Ho32286 \\
\hline CWII 27106 & & F. rablowebanam & & Sucd patus $s a$ & & Fulan Crina & & MA Wroneid & Hosess 00 & 10030278 \\
\hline CMN $2721^{\circ}$ & $\cos 227194$ & F. Coblowechenum & & Sucdintus re & & Fular China & & M.I Wirghesd & HCACPOS & Hos3224 \\
\hline CDAN 7063 & & Gulgrevite phibprino & & Tomindio bececto & & Natherianch & & H.A van dor Aat & $\operatorname{s} 236066$ & Ayzaenos \\
\hline CMN 2780 n & & Lesiadplod bo monopargare & & T. sesappos & & Madrgacers & & I Fow & F.rooses6 & Furoced1 \\
\hline CMN 278xo & & L maraingare & & $T$ odappos & & Madrosacer & & I Fow & Fnowes? & Fuxoeds \\
\hline $\operatorname{cBs} 35650$ & & Lesidalod te parve & & Thascoume ceces & & Srlake & & A Foperboch & EF62002 & EER2:062 \\
\hline $\cos 49478$ & & Lpara & & Cesasen neva of & & Coctitis & & o. Fingel & gr6rapet & EFEOTS4 \\
\hline STE-U SEOA & & Laslodplodis plungase & & Punussdo & & South Arrica & & U. Damm & $85+4562$ & ES445306 \\
\hline STEN 4589 & & L plutvas & & nilo anias & & Sout Afres & & F. Heteen & $4 \times 36482$ & ES445306 \\
\hline OWW $245 O^{j i t}$ & & 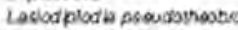 & nas & Eucd,pers so & & Ganoxi chiva & & Md Wrokits $A$ X D zhew & Hoc32011 & $1033220 \%$ \\
\hline CWN $2+800^{\circ 4}$ & & L. psoutrolvactromes & & Eucd patus sa. & & Guangxi Cina & & M.d Wrofieid \& XD. Ztow & $H 006290$ & 10,302008 \\
\hline Cas $116+50$ & & 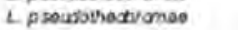 & & Griolino atsaras & & $\operatorname{coses} F \operatorname{sen}$ & & 1. Carners Welasquez & 85620077 & घस्2505? \\
\hline Cas 30479 & & L psoustathactranoo & & Rxasp. & & Nathenards & & $\mathrm{Na}$ & 856:0079 & ERe20061 \\
\hline CON $24701^{\circ 11}$ & & Lesiadiplad b thootromes & & Eucdpotus as & & Quangli China & & 14.J Wrofkid $\triangle \times D$ Z tha & Hoes nos & 10300200 \\
\hline OWN $2400^{\circ 11}$ & & L. thacearses & & Sucdpolus is & & Ganoxictins & & Md Wrofeid SXD Ztow & Hocos204 & 1033220 10 \\
\hline CMA $+84 x$ & ВоT & L machorese & & Casuarno cuninghame & & Wands & & J. Fow & D0106534 & $00 \times 3564$ \\
\hline CMN 9074 & & L. thactromes & & Plous a & & Maxice & & T. Busous & A)236052 & Arzses01 \\
\hline CBS 16406 & & I thacheomos & & Fut alcrg corel hest coare & & Now G.hes & & $\mathrm{Na}$ & Arewass & AYedcoss \\
\hline $\operatorname{cas} 11150^{\circ}$ & & 1. thactromes & & $\mathrm{Na}$ & & $\mathrm{Na}$ & & $\mathrm{Na}$ & 85620074 & EEOZOSA \\
\hline CMN 13511 & WAC 12530 & Laslat platb vanasuabreis & & 2. menoum & & tearigs Vorease & & 8 Machal & DO10Gsa7 & Da noses \\
\hline WRC 12540 & & L. venosuabres & & A meroum & & Menezisia & & 8 Matral & Do10asa7 & Da xosen \\
\hline CAN 28316 & & 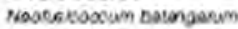 & & Tarmidie catappa & & Comencen & & D. Begade S I Fas & F.500006 & FI90660 \\
\hline CMN 28363 & & $M$ batanganim & & T. ozopas & & Camencon & & D Begade of i foux & F.000607 & Finco6s: \\
\hline CMN 13902 & $\cos$ toses4 & 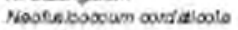 & & syrypum ondatum & & sodwars aey, sat $A$ & & D. Pavic & E.e2:898 & Eue218ea \\
\hline COA IA151 & CBS +23697 & $n$ sardatioab & & s. partotum & & Sebx South Atice & & D. Pavise & Buesmas & EUe21962 \\
\hline CAN 10135 & CBS 11579 & Pigates booxum sucaypur is & & E gronds & & Mamalange sout at & & H. Smin & 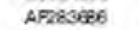 & AY23e291 \\
\hline CON 11705 & & $n$ agcdysuan & & E N N & & Soun ANroa & & B. \$loows & Arsap248 & Avaseget \\
\hline$C M N 14023$ & $\cos 12363$ & Nadecieascum Mmartcana? & laves & 5. cardatum & & Kimartoramol soath. & uca & D Pavic & E. $822 \times 00$ & Bueztero \\
\hline CMN 14123 & c8s 0386 & N. Swanbonambianso & & s candatum & & Fcads aby south kr & & D. Pavic & Euse2804 & EUe21564 \\
\hline CIN 5079 & IOA DCS & Nautsileoosum parwn & & Actirite do beses & & Now Zealond & & SR Perryoock: & Avasesti & AY23a36 \\
\hline CMW SCB1 & CMP 8000 & $M$ parrim & Papur & us xpot & $\mathrm{Ne}$ & earand & G.J & Samuda & arzenen 3 & Arzames \\
\hline COEW SOA & $A \pi C C B 89$ & $A$ parem & $r$ & syloosers & 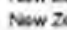 & ediand & G.J & Sarcoda & AFISTOS & AY230883 \\
\hline CNW 247CA & & $\alpha$ parwom & $E g r a$ & nols tyerid & G.sng & no aine & M.J. & Wholsds Xo tha & Haserzol 1 & Hosesen 17 \\
\hline CNW127100 & & up pasum & secol & petus op & Fulan & Crine & M.J & Whoneld & -10302302 & Hocese2 18 \\
\hline CMW2711 & & $\alpha$ perwom & Eusd & petus so. & Fular & Crins & MS & Whoned & $\rightarrow 035203$ & Hoses 2 \\
\hline CNW227128"t & & 1. pasum & $E$ ao & aryda $\times \in$ E gundb done & Fulan & Chine & M.J. & 1. Whondd & -0302204 & Hoseser2so \\
\hline CNW $27135^{\circ}$ & & $N$ parnom & $E$ din & & Fulan & Chine & n.J. & Whondd & $-10302 \times 6$ & Hose226 \\
\hline cosw $7 m 2$ & & Fiadusionosum / bis & Rbos & & Now $Y$ & os. Ust & B s & Slppens $\& G$ Heder & Avrsenas & Av23e8n \\
\hline Cow $7 m 3$ & & un xhis & Rbos & & New $x$ & CA USA & B 8 & Slpass \& G Hater & arzaseses & AY2se878 \\
\hline CNW127100 & & $A$ nols \& 2 & Eucd & peus $s p$ & Fulan & Chins & & Whofisd & $\rightarrow 0352306$ & ncasenas \\
\hline CAN 9458 & Cas 129645 & $x$ undantoob & s. con & dotum & Koil B & sy seuth arkea & D. P & pale & ELE21904 & Euesigi4 \\
\hline CANW 14127 & CBS 12064 & Ne uribanibabo & $s \infty a r$ & ctatum & Kwant & cenarrol Scuth Atres & $D P$ & pavic & EᄂE21926 & Eue21856 \\
\hline
\end{tabular}

Na Nor aralatie

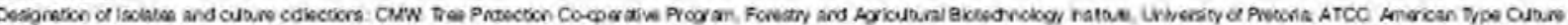

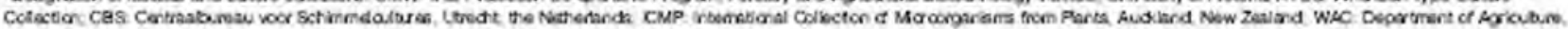

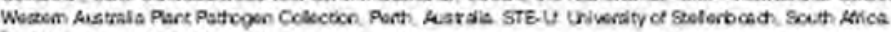

tsdaxa sequenced in tis stsog, are dien in bold

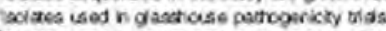

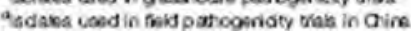

By using the Markov Chain Monte Carlo (MCMC) method, Bayesian analyses were performed to ascertain the topology of the trees obtained with paup. These were conducted on the combined datasets of ITS and TEF- $1 \alpha$ sequences as used in the parsimony analysis. First MrModeltest v.2.3 (Nylander, 2004) was used to determine the best nucleotide substitution model. Phylogenetic analyses were performed with MrBayes v. 3.1 (Ronquist \& Huelsenbeck, 2003). GTR+G was chosen as best-fitting model for the ITS and TEF-1 $\alpha$ combined dataset. Two independent runs of MCMC with four chains were run for 1000000 generations. Trees were sampled every 100th generation for a total of 10000 trees. The first 1000 trees were discarded as the burn-in phase of 
each analysis, well after the likelihood values converted to stationary, leaving 9000 trees from which the consensus trees and posterior probabilities were calculated. The sequence of Guignardia philoprina from GenBank was used as the outgroup taxon (Table 1).

\section{Morphology}

Single-spore cultures of each species identified using DNA sequence data were transferred to WA media with sterilized pine needles placed on the agar surface and incubated at $25^{\circ} \mathrm{C}$ to induce sporulation. Released conidia from the pycnidia formed on pine needles were mounted in $85 \%$ lactic acid on glass slides and examined microscopically. Digital images were taken using a light microscope, a HRc Axiocam digital camera and accompanying software (Carl Zeiss Ltd.). Widths and lengths of 20 conidia were measured for each taxon and average (mean), standard deviation (std. dev), minimum (min) and maximum (max) measurements presented as [(min-) (average-std. dev.)-(average + std. dev.)(-max)], and their length: width ratios were calculated. The morphology of fungal colonies and the growth rates of cultures were conducted following the method described in Begoude et al. (2010b).

\section{Pathogenicity tests}

\section{Glasshouse trial}

Fourteen isolates, representing different species of the Botryosphaeriaceae identified based on PCRRFLP fingerprinting, anamorph morphology and DNA sequence comparisons were used in a glasshouse pathogenicity trial (Table 1). These isolates were randomly selected to represent different locations and hosts. Six-day-old isolates grown on $2 \%$ MEA at $25^{\circ} \mathrm{C}$ were used for inoculations.

Trees of a Eucalyptus grandis clone (TAG-5) were selected for pathogenicity tests under glasshouse conditions. The trees were approximately $2 \mathrm{~m}$ tall and had diameters of approximately $10 \mathrm{~mm}$. Before conducting the inoculations, the trees were allowed to acclimatize to the glasshouse conditions of $25^{\circ} \mathrm{C}$ and $14 \mathrm{~h}$ daylight, with $10 \mathrm{~h}$ darkness, for 1 month. Each of the 14 selected isolates was inoculated into the stems of 10 trees. Ten trees were also inoculated with sterile MEA plugs to serve as controls. The total of 150 inoculated trees was randomly arranged in a glasshouse.

For inoculations, wounds were made on the stems of the plants using a $6 \mathrm{~mm}$ diameter cork borer to remove the bark and expose the cambium. Wounds were made on the stems of the trees, approximately $300 \mathrm{~mm}$ above soil level. Plugs of mycelium were taken from 10-day-old cultures grown on MEA using the same size cork borer, and were placed into the wounds with the mycelium facing the cambium. Inoculated wounds were sealed with laboratory film (Parafilm M, Pechiney Plastic Packaging) to prevent desiccation and contamination.

After 6 weeks, the bark of the inoculated plants was removed and internal lesion lengths $(\mathrm{mm})$ on the cambium were measured. The inoculated fungi were re-isolated by cutting small pieces of wood from the edges of lesions and plating them on $2 \% \mathrm{MEA}$ at $25^{\circ} \mathrm{C}$. Re-isolations were made from four randomly selected trees per isolate and from all trees inoculated as controls. Results were analysed in sas (Version 8) using proc glm (General Linear Model) (SAS Institute, 1999). Analysis of variance (anova) was used to determine the effects of fungal strain on lesion length. Prior to anova, homogeneity of variance across treatments was verified. To test the significance of the comparison means, Fisher's protected test was used and $\mathrm{F}$ values with $\mathrm{P}<0.05$ were considered significant. 
The eight most aggressive isolates identified in the glasshouse trial, belonging to five different species of Botryosphaeriaceae, were selected for field inoculations in China (Table 1). The field inoculations were conducted in an experimental Eucalyptus plantation in the ZhanJiang area of South China. Five Eucalyptus genotypes (1-year-old, 40-70 mm diameter), commonly grown in commercial plantations in South China were used in the field trial. These included an E. grandis clone (CEPT-1), an E. grandis $\times$ E. tereticornis clone (CEPT-2), an E. pellita genotype (CEPT-3), an E. urophylla $\times$ E. grandis clone (CEPT-4) and an E. urophylla clone (CEPT-5). Each of the eight isolates was inoculated into eight trees for every Eucalyptus genotype. Eight trees of each Eucalyptus genotype were also inoculated with sterile MEA plugs to serve as controls.

Inoculations were made on the stems of trees $50-100 \mathrm{~cm}$ above the soil level. A 9-mm-diameter sterile metal cork borer was used to remove the bark and to expose the cambial layer. Discs of mycelium of the same size were taken from 7-day-old cultures and placed into the exposed wounds with the mycelium facing the cambium. The inoculated wounds were sealed with Parafilm to protect them from desiccation and contamination. The inoculations were conducted in OctoberNovember, 2008. Internal lesion lengths in the cambium were measured after 5 weeks. Results from the field trial were analysed in sas (Version 8) using proc glm (SAS Institute Inc., 1999) and in a similar manner to those for the glasshouse inoculation test.

\section{Results}

\section{Isolates}

Forty-eight isolates of Botryosphaeriaceae were collected from 14 trees in three provinces during collection trips in 2006 and 2007 (Table 1). Six of these isolates were collected from a single $E$. grandis hybrid tree and two trees of an unknown Eucalyptus clone at two sites in GuangXi Province in November of 2006. Three isolates were each collected from three different trees of an $E$. urophylla $\times$ E. tereticornis clone at a site in the HaiNan Province in June of 2007. Thirty-nine isolates were collected from four different sites in FuJian Province in September of 2007, nine isolates were collected from a single E. urophylla $\times$ E. grandis clone at one site, four isolates from two trees of an E. dunnii clone at another site, and 26 isolates were collected from five trees of an unknown Eucalyptus sp. at two different sites. Nine isolates from the GuangXi and HaiNan Provinces were collected from diseased twigs, while the 39 isolates from FuJian Province were collected from senescing twigs on different trees (Table 1).

\section{PCR-RFLP analysis}

The 48 isolates of Botryosphaeriaceae from South China were separated into four groups based on PCR-RFLP profiles. After digestion of ITS rDNA amplicons with $C f o$, the 48 isolates were separated into three groups (Fig. 1a-b). These profiles were compared with those published by Slippers et al. (2004b). Four isolates, identified as Lasiodiplodia spp. based on morphology, produced the same profile (Group 1) (Fig. 1a) and 17 isolates in Group 2 represented members of the $N$. parvum/N. ribis complex (Fig. 1a-b). Profiles of 27 isolates in Group 3 matched those of the $B$. dothidea complex or $N$. luteum/N. australe (Fig. 1a-b). The ITS amplicons of these isolates were therefore also digested with $K s p \mathrm{I}$ and identified as B. dothidea complex (Fig. 1c).

The 17 isolates residing in the $N$. parvum/N. ribis complex (Group 2) produced two profiles after digestion of BotF15 and BotF16 amplicons with $C f o$ I (Fig. 1d). These profiles matched those of $N$. parvum (16 isolates) and N. ribis s. $l$. (one isolate) as described by Slippers et al. (2004b). 

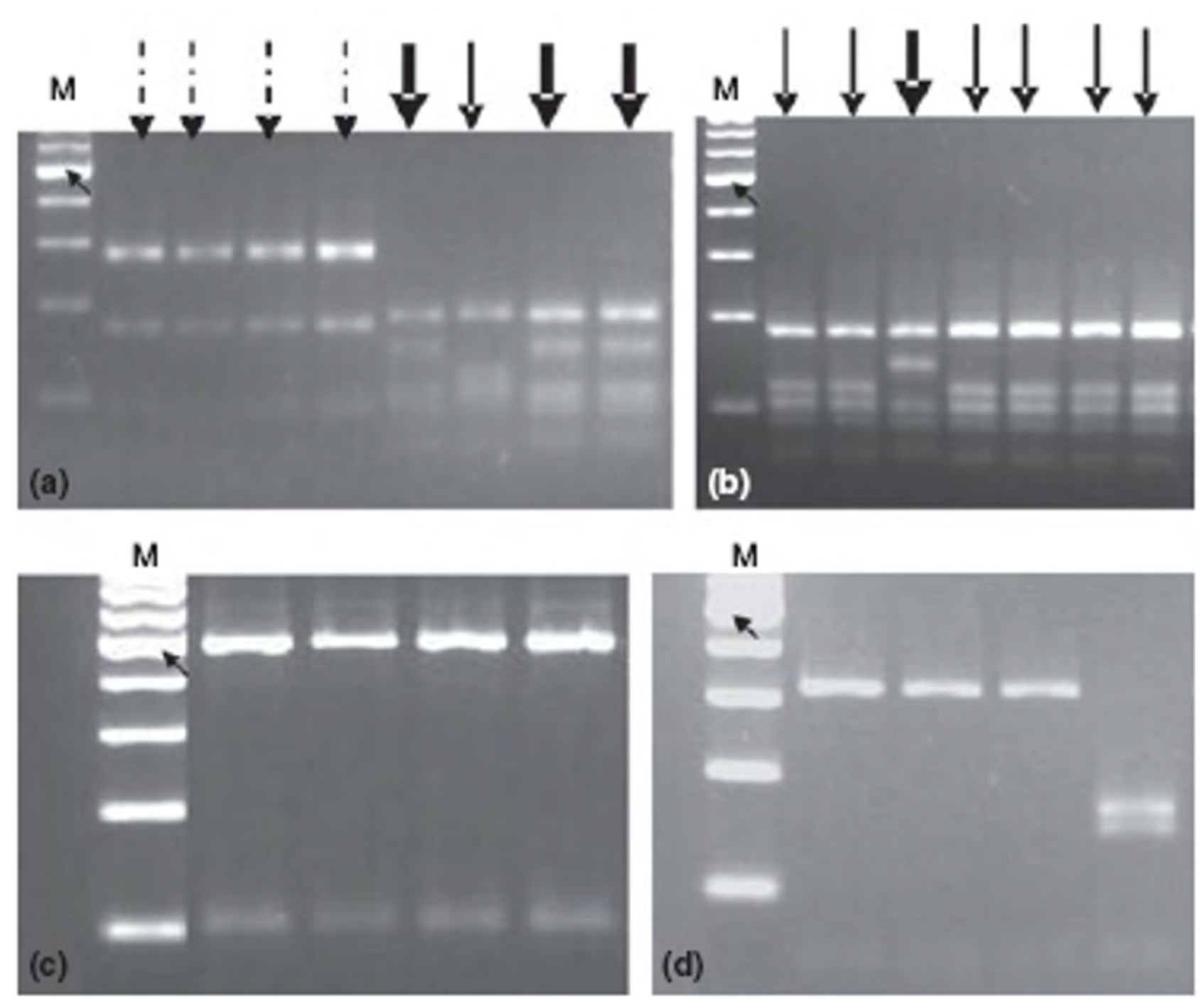

Figure 1. Agarose gel showing $C f o$ I restriction fragments of the ITS and DNA locus BotF15 PCR, and KspI restriction fragments of the ITS PCR products of different clades of Botryosphaeriaceae from China. (a-b) All the isolates are distinguished into three groups by using restriction enzyme CfoI to digest ITS PCR products, (a) Group 1 (dash arrow): Lasiodiplodia pseudotheobromae and L. theobromae, (a-b) Group 2 (bold arrow): Neofusicoccum parvum/N. ribis species complex; Group 3 (thin arrow): species within Botryosphaeria dothidea complex; (c) ITS PCR products of isolates of $B$. dothidea complex digested by restriction enzyme KspI; (d) DNA locus BotF15 PCR products of isolates of $N$. parvum/N. ribis species complex digested by restriction enzyme $C f o$ I, one isolate is in group of $N$. ribis s. $l$, and other isolates in $N$. parvum. The oblique arrow indicates the $500 \mathrm{bp}$ marker, and lane ' $\mathrm{M}$ ' contains a $100 \mathrm{bp}$ size marker.

\section{Phylogenetic analysis}

The partition homogeneity test comparing the ITS and TEF-1 $\alpha$ datasets gave a PHT value of $\mathrm{P}=$ 0.297 , indicating that these two datasets were congruent and could be combined in the phylogenetic analysis. The aligned sequences of the combined datasets were submitted to TreeBASE (11035; http://www.treebase.org), and consisted of 863 characters of which 481 were constant and 382 were parsimony informative. Heuristic searches resulted in 20 most parsimonious trees. A consensus tree $(50 \%$ majority rule) (tree length $=784$ steps; $\mathrm{CI}=0.802 ; \mathrm{RI}=0.969 ; \mathrm{RC}=0.777)$ was computed (Fig. 2; TreeBASE 11035). 


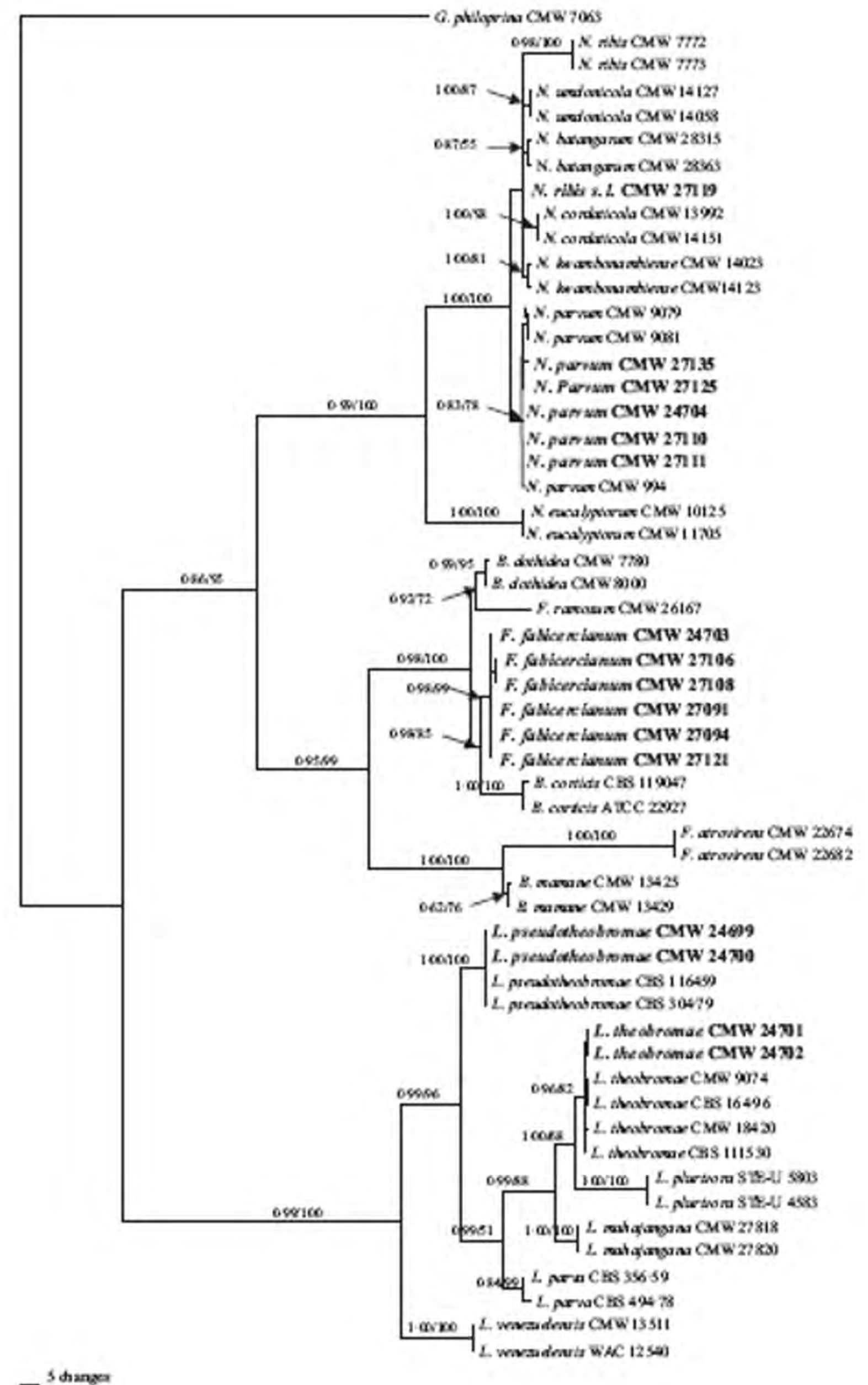


Figure 2. One of the 20 most parsimonious trees obtained from Maximum Parsimony analysis of the combined ITS and TEF- $1 \alpha$ sequence data of the representative taxa of the Botryosphaeriaceae. Posterior probabilities followed by bootstrap support (\%) from 1000 replications are given on the branches (PP/BS). Isolates marked in bold represent those obtained from Eucalyptus trees in China.

In the Bayesian analysis, the position of the genera in relation to each other was different, but within each genus the topology was similar to the parsimony tree (TreeBASE 11035). Three clades were identified, each corresponding to a separate genus and each supported with high Bayesian posterior probabilities (PP) and bootstrap support (BS) (Fig. 2, $\mathrm{PP}=0.99, \mathrm{BS}=100 \%$; $\mathrm{PP}=0.95$, $\mathrm{BS}=99 \% ; \mathrm{PP}=0.99, \mathrm{BS}=100 \%$, respectively). These were Clade 1 (Neofusicoccum), Clade 2 (Botryosphaeria) and Clade 3 (Lasiodiplodia). Within the Neofusicoccum clade, a single Chinese isolate was phylogenetically distant from other species within this clade, while other Chinese isolates in this clade resided with $N$. parvum. Within the Botryosphaeria clade, the Chinese isolates were found to be distinct from the known species in the genus by congruent distinction in both the datasets, and high Bayesian posterior probability and high bootstrap value ( $\mathrm{PP}=0.98, \mathrm{BS}=99 \%)$, suggesting that they represent an undescribed species. Within the Lasiodiplodia clade, the isolates in this study resided in clades identified as L. theobromae and L. pseudotheobromae, respectively (Fig. 2).

\section{Morphology and taxonomy}

All 48 isolates of the Botryosphaeriaceae from Eucalyptus plantations in South China produced anamorph fruiting structures on pine needles on WA media within 2-3 weeks. Teleomorph structures were not observed. All isolates were separated into two main groups based on conidial morphology. Forty-four isolates produced hyaline, Fusicoccum-like conidia, and four isolates produced dark, septate and striate conidia typical for Lasiodiplodia spp. Based on PCR-RFLP fingerprinting, anamorph morphology and DNA sequence comparisons, five species were identified. The conidial morphology of the four species and taxonomy of the undescribed species are described below.

Two isolates from one tree of an unknown Eucalyptus sp. in GuangXi Province were identified as L. pseudotheobromae. Conidia of L. pseudotheobromae were ellipsoidal, apices and bases rounded, widest in their middle to upper two-thirds, thick-walled, initially hyaline and aseptate, becoming one-septate and dark walled, (26.5-) 27-29(-30.5) $\times(13-) 14.5-16(-17) \mu \mathrm{m}$ (average of 40 conidia $28.1 \times 15.2 \mu \mathrm{m}, 1 / \mathrm{w} 1.8)$ (Fig. 3a).

Two isolates from a single unknown Eucalyptus tree in GuangXi Province were identified as $L$. theobromae. Conidia of $L$. theobromae were ellipsoid or oblong, broadly rounded at their apices, tapering to truncate bases, widest in their middle to upper one-quarter sections, initially hyaline and aseptate, becoming one-septate and dark brown, (22.5-)23.5-26(-27) $\times(12-) 13-14.5(-16) \mu \mathrm{m}$ (average of 40 conidia $24.7 \times 13.9 \mu \mathrm{m}, 1 / \mathrm{w} 1.8$ ) (Fig. 3b).

Conidia of isolates identified as $N$. parvum and N. ribis $s$. $l$. were fusiform to ellipsoidal, aseptate, hyaline, smooth with granular contents. Conidia of $N$. parvum (Fig. 3c) were (16.5-)17-20(-23.0) $\times$ (5-)5.5-6.5(-7) $\mu \mathrm{m}$ (average of 100 conidia $18.7 \times 6.0 \mu \mathrm{m}, 1 / \mathrm{w} 3.1$ ) and $N$. ribis s. l. (Fig. 3d) were $(19-) 19.5-21(-22.5) \times(5.5-6.5) \mu \mathrm{m}$, (average of 20 conidia $20.6 \times 6.0 \mu \mathrm{m}, 1 / \mathrm{w} 3.5$ ). Sixteen isolates were identified as $N$. parvum. One isolate was from a single E. grandis hybrid tree in GuangXi Province, 15 isolates from FuJian Province, including four isolates from two trees of an unknown Eucalyptus sp., seven isolates from a single E. urophylla $\times$ E. grandis tree and another four isolates from two E. dunnii trees. One isolate, from a single unknown Eucalyptus tree in FuJian Province was identified as $N$. ribis s. $l$. 

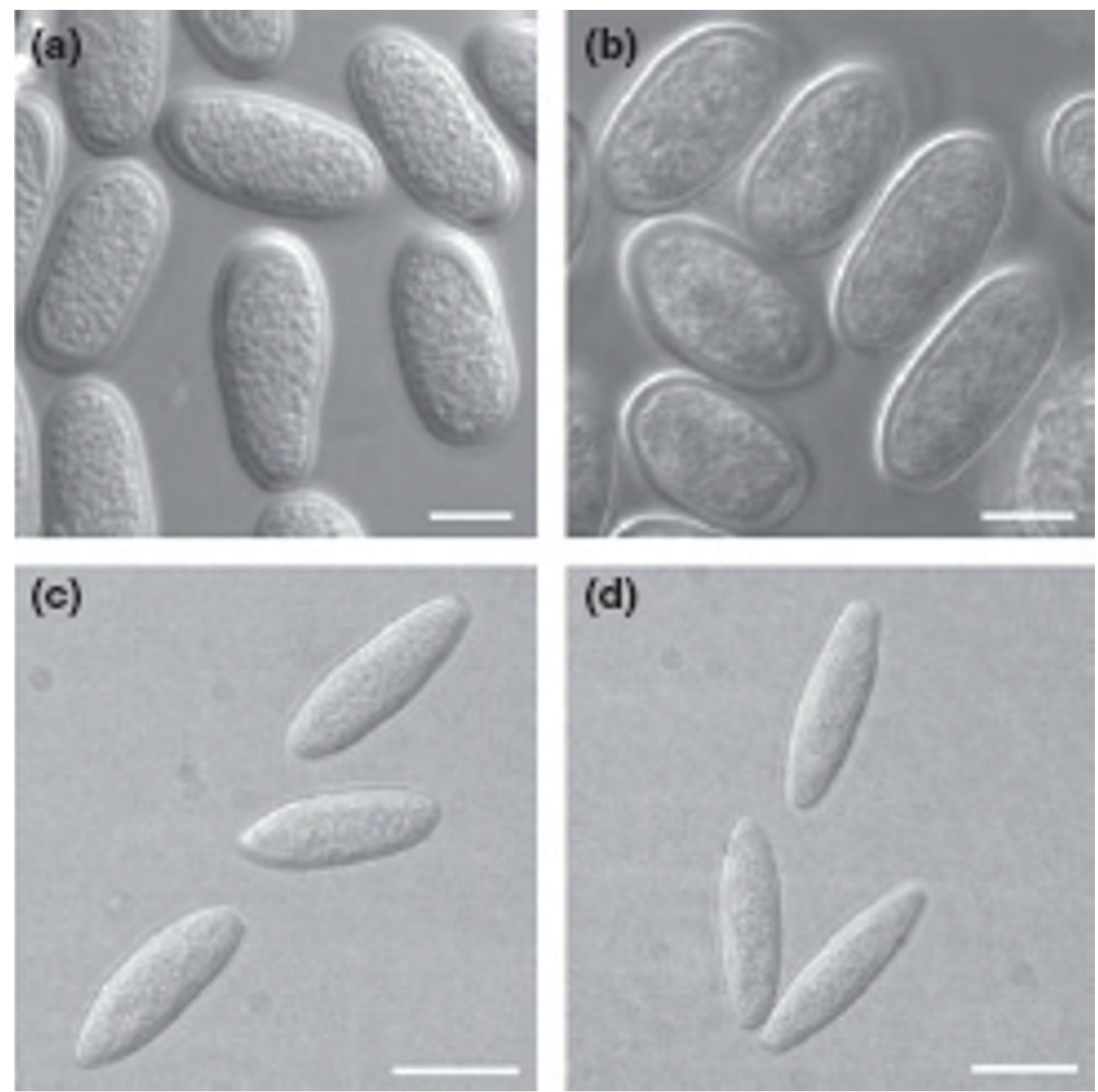

Figure 3. Conidia of Lasiodiplodia, Fusicoccum and Neofusicoccum species isolated from Chinese Eucalyptus plantations. (a) Lasiodiplodia pseudotheobromae; (b) L. theobromae; (c) Neofusicoccum parvum; (d) N. ribis s. 1 . Bars $=10 \mu \mathrm{m}$.

Fusicoccum fabicercianum S.F. Chen, D. Pavlic, M.J. Wingf. \& X.D. Zhou, sp. nov., MycoBank No. MB519065

Etymology: Name refers to the co-operation between FABI (Forestry and Agricultural Biotechnology Institute, South Africa) and CERC (China Eucalypt Research Centre, China), that led to the discovery of this new species (Fig. 4).

Conidiomata superficialia solitaria vel aggregata atrobrunnea globosa, hyphis vel mycelio tecta. Conidiophorae absunt. Cellulae conidiogenae cylindricae vel lageniformes, hyalinae laeves parietibus tenuibus holoblasticae conidium unicum in apice formantes. Paraphyses absunt. Conidia hyalina parietibus tenuibus laevia contento granuloso, unicellularia non septata, fusiformia medio vel in tertia parte summa latissima, apice acuta, basi truncata fimbriis minutis marginalibus, mediocriter $22.0 \times 5.8 \mu \mathrm{m}, 3.8$-plo longiora quam latiora; unum vel duo septa ante germinationem formantes. 

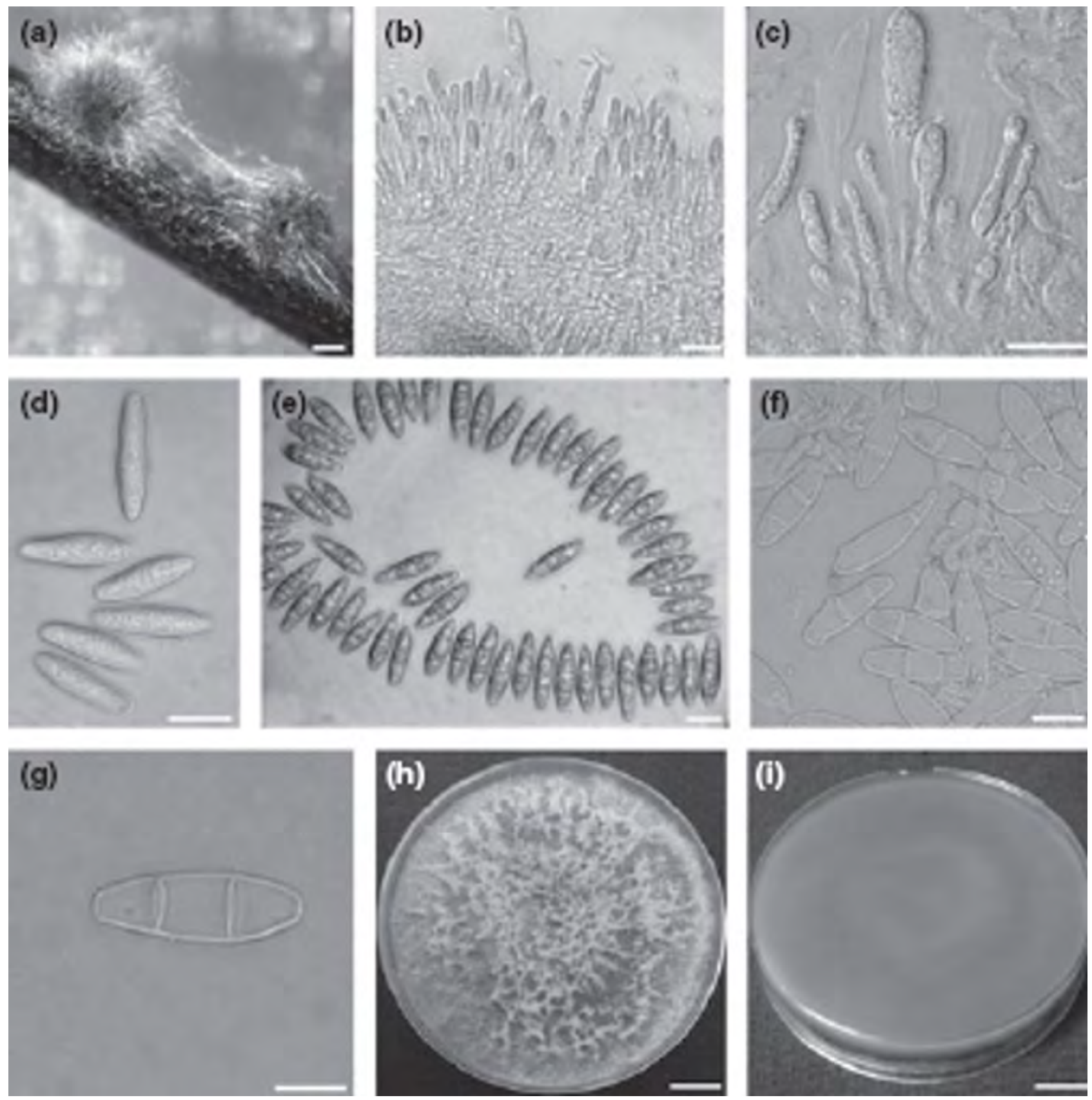

Figure 4. Fusicoccum fabicercianum CMW 27094 = CBS 127193 (culture ex-epitype). (a) Conidiomata formed in culture on pine needle; (b) immature, developing conidia produced by conidiogenous cells; (c) conidiogenous cells and developing conidia; (d) smooth, aseptate, fusiform mature conidia; (e) mature conidia with granular contents; (f) germinating conidia with one or two septa; (g) a typical germinating conidium with two septums; (h) living culture after growing 10 days on MEA (front); (i) living culture after growing 10 days on MEA (reverse). Bars: $\mathrm{a}=100 \mu \mathrm{m}$; $\mathrm{b}-\mathrm{g}=$ $10 \mu \mathrm{m} ; \mathrm{h}-\mathrm{i}=10 \mathrm{~cm}$.

Conidiomata developing in culture on pine needles after 10 days and producing conidia after 14 days, superficial, solitary to aggregated, dark brown, globose, covered with hyphae/mycelium, diameter (245-)346-470(-525) $\mu \mathrm{m}$ (average of 50 conidiomata $408 \mu \mathrm{m}$ ); wall composed of three layers: an outer thick-walled dark to light brown textura angulari; a middle layer of thin-walled light brown cells; and an inner layer of thin-walled hyaline cells (Fig. 4a). Conidiophores absent. Conidiogenous cells (Fig. 4b-c) cylindrical to lageniform, hyaline, smooth, thin-walled, holoblastic producing a single conidium at the tip, rarely proliferating at same level giving rise to periclinal thickenings, $(6.5-) 10.5-13.5(-16.0) \times(2.0-) 2.5-3.5(-4.5) \mu \mathrm{m}$ (average of 50 conidiogenous cells 12.0 $\times 3.0 \mu \mathrm{m})$. Paraphyses absent. Conidia (Fig. 4d-g) hyaline, thin-walled, smooth (Fig. 4d) with 
granular contents (Fig. 4e); unicellular, aseptate, fusiform, widest in the middle to upper third, apex acute, base truncate with a minute marginal frill, (16.7-)19.6-24.4(-26.1) $\times(4.5-) 5.2-6.4(-7.5) \mu \mathrm{m}$ (average of 100 conidia $22.0 \times 5.8 \mu \mathrm{m}, 1 / \mathrm{w}=3.8$ ); forming one or two septa before germination (Fig. 4f-g).

Culture characteristics: Colony mycelium fluffy, initially white turning smoke grey (21"'"f) from the middle of colonies within 4-6 days, with an appressed mycelial mat, sparse to moderately dense. Cottony aerial mycelium toward the edge of colony, becoming pale olivaceous grey (21"'"d) to olivaceous grey (21"'"i), and greenish black (33"'"'k) (reverse) within 12-16 days (Fig. 4h-i). Optimal temperature for growth $25(-30)^{\circ} \mathrm{C}$, colony covering the $90 \mathrm{~mm}$ diameter Petri dish after 5 days in the dark.

Teleomorph: Not observed, but expected to be Botryosphaeria-like based on phylogenetic inference.

Habitat: Branches and twigs of Eucalyptus species and hybrids.

Hosts and distributions: Eucalyptus urophylla $\times$ E. grandis and a Eucalyptus sp. in FuJian Province; E. urophylla $\times$ E. tereticornis in HaiNan Province; Eucalyptus grandis hybrid in GuangXi Province; China.

Specimens examined: CHINA. FuJian Province, from senescing twigs of an unknown Eucalyptus sp. Aug., 2007, M.J. Wingfield, Herb. PREM 60449, holotype of F. fabicercianum sp. nov., culture ex-type CMW $27094=$ CBS 127193; FuJian Province, from senescing twigs of unknown Eucalyptus sp. Aug., 2007, M.J. Wingfield, Herb. PREM 60450, culture CMW $27121=$ CBS 127194; GuangXi Province, from senescing twigs of Eucalyptus grandis hybrid, Nov., 2006, M.J. Wingfield \& X.D. Zhou, culture CMW 24703 = CBS 127187; HaiNan Province, from diseased living twigs of E. urophylla $\times$ E. tereticorni; June, 2007, M.J. Wingfield \& X.D. Zhou, culture CMW 27091.

Notes: Fusicoccum fabicercianum sp. nov. is morphologically similar to Botryosphaeria corticis, but can be distinguished from that species by having smaller conidiogenous cells and smaller conidia. Botryosphaeria corticis: conidiogenous cells $12.5-17.5 \times 2.5-4.5 \mu \mathrm{m}$, conidia (20.5-)23.5$32.5(-34.5) \times(5-) 5.5-7(-7.5) \mu \mathrm{m}$, av. $=28.9 \times 6.4 \mu \mathrm{m}, 1 / \mathrm{w}=4.5$ (Phillips et al., 2006). Compared to the conidial morphology of other species of Fusicoccum, the conidia of $F$. fabicercianum sp. nov. are larger than those of $F$. ramosum $(13.4 \times 5.7 \mu \mathrm{m}$ in culture) (Pavlic et al., 2008), similar to $B$. dothidea $(24.7 \times 4.9 \mu \mathrm{m}$ in culture, $19.6 \times 4.8 \mu \mathrm{m}$ on a natural Prunus sp.) (Slippers et al., 2004a), smaller than $F$. atrovirens $(33.5 \times 8.5 \mu \mathrm{m}$ in culture) (Mehl et al., 2010) and B. mamane $(33.5 \times 6.1$ $\mu \mathrm{m}$ in culture) (Mohali et al., 2007). Fusicoccum fabicercianum sp. nov. is also characterized by one or two septa that develop in the conidia before germination, which is not uncommon amongst species of Botryosphaeria (Slippers et al., 2004a).

Twenty-seven isolates were identified as $F$. fabicercianum sp. nov. in this study. One isolate was from a single unknown E. grandis hybrid tree in GuangXi Province, three isolates were from three different trees of an E. urophylla $\times$ E. tereticornis clone in the HaiNan Province, 21 isolates were from four trees of an unknown Eucalyptus sp. and an additional two isolates from a single $E$. urophylla $\times$ E. grandis tree were identified from the FuJian Province. 


\section{Pathogenicity tests}

\section{Glasshouse trial}

All isolates of the Botryosphaeriaceae inoculated on the Eucalyptus clone TAG-5 produced lesions within 6 weeks, while only small lesions were produced in the controls (Fig. 5). The comparison of means showed that the lesions produced by the isolates of Botryosphaeriaceae were significantly longer than those of the controls $(\mathrm{P}<0.0001)$ (Fig. 5). The inoculated fungi were successfully reisolated from the lesions. Although small lesions were produced on the controls, no Botryosphaeriaceae were re-isolated from those trees.

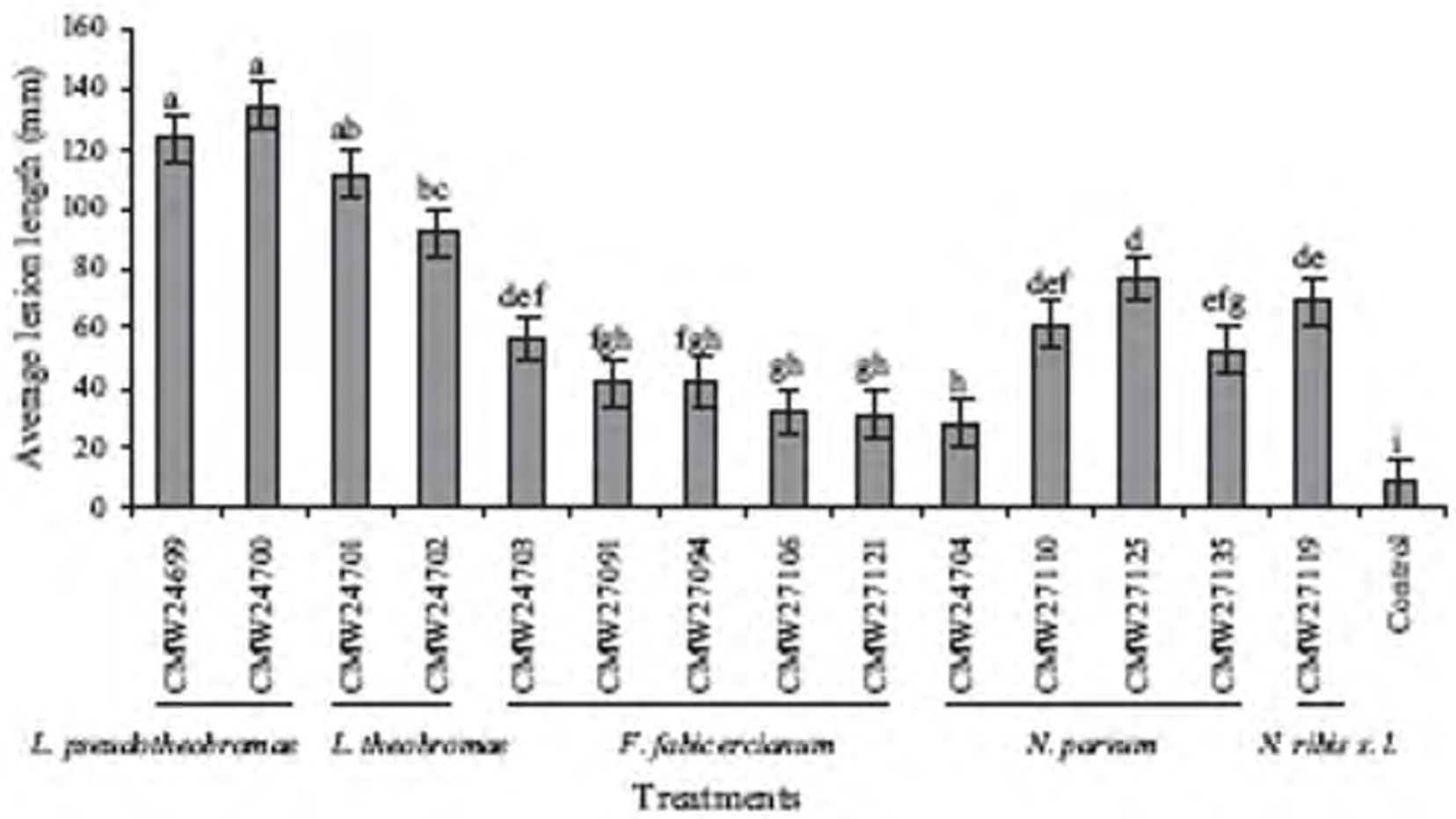

Figure 5. Column chart indicating the mean lesion lengths $(\mathrm{mm})$ resulting from inoculation trials with L. pseudotheobromae, L. theobromae, Fusicoccum fabicercianum, Neofusicoccum parvum and N. ribis s. l. onto E. grandis clone (TAG-5) under glasshouse conditions. Bars represent 95\% confidence limits for each treatment. Different letters above the bars indicate treatments that were significantly different $(\mathrm{P}=0.05)$.

The mean comparison tests showed that lesions produced by isolates of L. pseudotheobromae and $L$. theobromae were significantly longer than those induced by isolates of $F$. fabicercianum sp. nov., $N$. parvum and $N$. ribis s. $l$. $(\mathrm{P}<0.05)$ (Fig. 5). Isolates of L. pseudotheobromae were more aggressive than those of $L$. theobromae (Fig. 5). The two most aggressive isolates of each species of $L$. pseudotheobromae, L. theobromae and F. fabicercianum sp. nov., and one most aggressive isolate of $N$. parvum and $N$. ribis $s$. $l$. were selected for field inoculations.

\section{Field trial}

All isolates used in the field trial produced lesions on the Eucalyptus genotypes. Small lesions were also produced for the control inoculations but they were significantly shorter $(\mathrm{P}<0.05)$ (Fig. 6). anovas showed significant isolate $\times$ genotype interaction $(\mathrm{P}<0.0001)$, indicating that not all the Botryosphaeriaceae isolates reacted in the same manner to all the tested Eucalyptus genotypes, and this was supported by the mean comparison test results. For example, lesions produced by $L$. pseudotheobromae on Eucalyptus genotypes CEPT-1, CEPT-2 and CEPT-4 were significantly 
longer than those on CEPT-3 and CEPT-5 (P < 0.05) (Fig 6), while no significant differences in lesion length were found for the five Eucalyptus genotypes inoculated with isolates of $F$. fabicercianum sp. nov. $(\mathrm{P}>0.05)$ (Fig. 6). Similar to the glasshouse inoculations, $L$. pseudotheobromae was found to be the most aggressive pathogen.

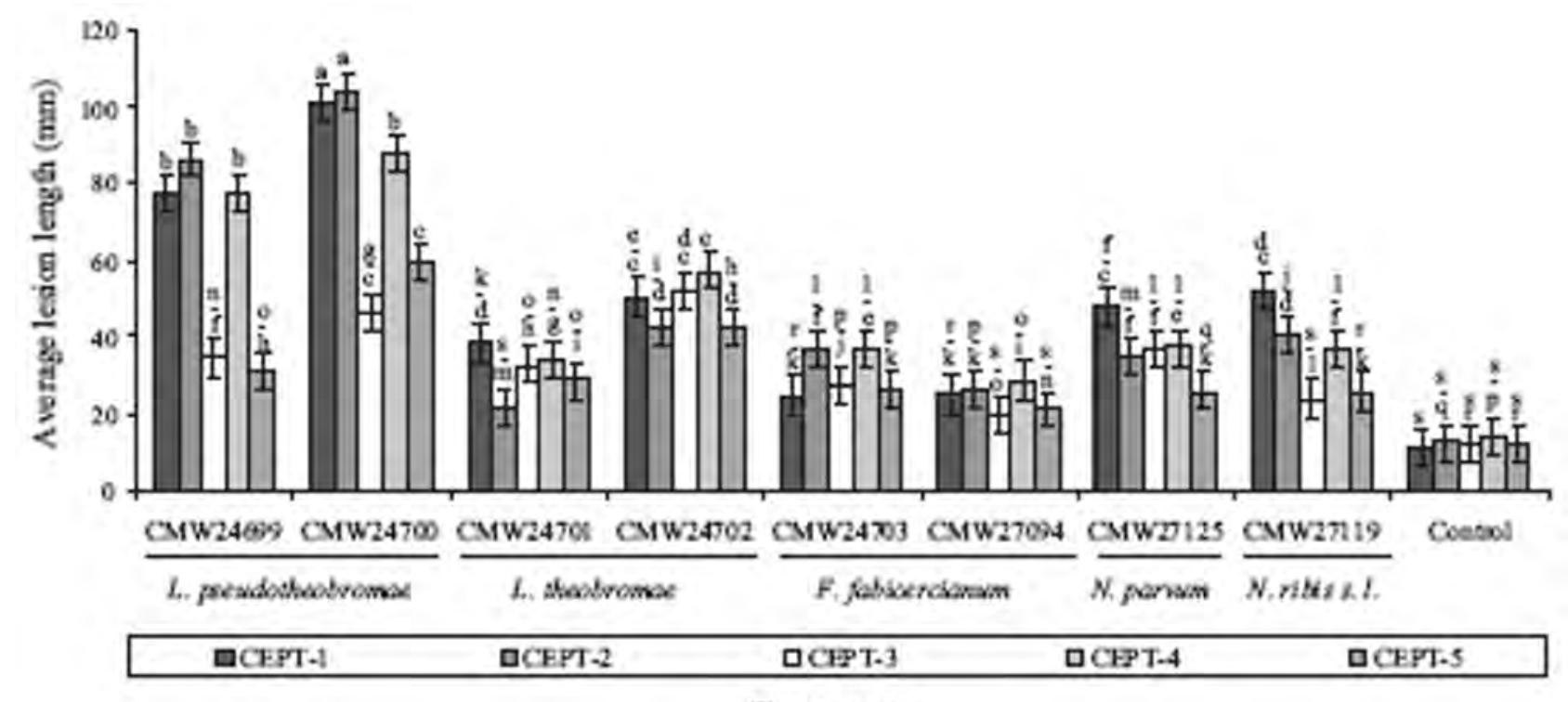

Treatments

Figure 6. Column chart indicating the mean lesion lengths $(\mathrm{mm})$ resulting from inoculation trials with Lasiodiplodia pseudotheobromae, L. theobromae, Fusicoccum fabicercianum, Neofusicoccum parvum and N. ribis s. l. onto five Eucalyptus genotypes in Chinese plantations. Bars represent 95\% confidence limits for each treatment. Different letters above the bars indicate treatments that were significantly different $(\mathrm{P}=0.05)$.

\section{Discussion}

This study represents the most comprehensive consideration of species of Botryosphaeriaceae from Eucalyptus spp. in China to date. Using comparisons of ITS rDNA and TEF-1 $\alpha$ sequence data combined with PCR-RFLP analysis and morphology of the anamorph structures, it was possible to identify five species from a relatively small collection of isolates. They included $L$. pseudotheobromae, L. theobromae, N. parvum, N. ribis sensu lato and F. fabicercianum sp. nov. Except for $N$. parvum (Slippers et al., 2009), all species are reported for the first time from Eucalyptus trees in China.

The distribution of the species collected in this study varied among the regions. Fusicoccum fabicercianum was found on diseased Eucalyptus trees in the GuangXi and HaiNan Provinces, and also on dying Eucalyptus twigs in FuJian Province. Lasiodiplodia pseudotheobromae and $L$. theobromae were identified on a diseased Eucalyptus sp. in GuangXi Province. Neofusicoccum parvum was found on diseased Eucalyptus trees in GuangXi Province and dying twigs in FuJian Province. Neofusicoccum ribis s. $l$. was collected from senescing twigs on a Eucalyptus sp. in FuJian Province. Fusicoccum fabicercianum sp. nov., N. parvum and N. ribis s. l. were isolated from senescing twigs on the same tree in FuJian Province, indicating that different species of Botryosphaeriaceae share the same ecological environment in China, which is similar to that found in other studies (Slippers \& Wingfield, 2007). The relatively limited distribution of $L$. pseudotheobromae and L. theobromae is most likely related to a collecting bias as these fungi are known from numerous countries, especially from tropical regions (Punithalingam, 1980; Mohali et al., 2005, 2007; Pavlic et al., 2007; Alves et al., 2008; Begoude et al., 2010a). 
Fusicoccum fabicercianum resides in the Botryosphaeria (anamorph Fusicoccum) clade of the Botryosphaeriaceae and pathogenicity tests indicate that it is a weak pathogen. Although the species was most commonly isolated in samples taken in three provinces of South China, it was less pathogenic than the other species collected. Phylogenetically, F. fabicercianum is closely related to Botryosphaeria corticis, B. dothidea and F. ramosum. Interestingly, the results further showed that Botryosphaeria spp. with Fusicoccum anamorphs clustered in two clades supported by high statistical values. One clade includes B. corticis, B. dothidea, F. fabicercianum and $F$. ramosum, while B. mamane and $F$. atrovirens reside in the other clade (Fig. 2). Previous studies have shown that there are conidial differences amongst the species residing in the two clades, for example the conidia of species in the former clade are shorter (average: $<30 \mu \mathrm{m}$ ) than those of B. mamane and $F$. atrovirens (average: more than $30 \mu \mathrm{m}$ ) (Slippers et al., 2004a; Phillips et al., 2006; Mohali et al., 2007; Pavlic et al., 2008; Mehl et al., 2010). More representative species and further work is needed to better understand the relevance of this divergence, and whether these groups validate distinct generic descriptions.

Neofusicoccum parvum is a well known pathogen of Eucalyptus spp. (Slippers et al., 2004b; Burgess et al., 2005; Pavlic et al., 2007; Slippers \& Wingfield, 2007; Mohali et al., 2009; Rodas et al., 2009). The pathogen has been identified from Eucalyptus trees in Australia (Slippers et al., 2004b), Africa (Gezahgne et al., 2004; Slippers et al., 2004b), South America (Mohali et al., 2007) and Southeast Asia (Slippers et al., 2009). Results of this study also showed that N. parvum was amongst the most pathogenic species except Lasiodiplodia spp., supporting the view that it is an important pathogen of Eucalyptus spp. (Slippers et al., 2004b; Slippers \& Wingfield, 2007).

The taxonomy of $N$. ribis and closely related species has been confused for many years. Isolates of $N$. ribis were initially separated from its sister species $N$. parvum, based on concordance between sequence data of multiple gene regions and PCR-RFLP analysis and were treated as $N$. ribis s. 1. (Slippers et al., 2004b). Subsequently, N. ribis has been reported from Eucalyptus in Australia (Barber et al., 2005), Colombia (Rodas et al., 2009) and Venezuela (Mohali et al., 2007). Recently, four species, $N$. batangarum, $N$. cordaticola, $N$. kwambonambiense and $N$. umdonicola were identified in the $N$. ribis s. $l$. complex based on multiple gene genealogies (Pavlic et al., 2009a,b; Begoude et al., 2010b). Thus, isolates previously identified as N. ribis based on PCR-RFLP analysis could represent any of a number of cryptic species. The isolate included in this study grouped closely, but separately from $N$. batangarum, $N$. cordaticola and $N$. umdonicola in the phylogenetic analysis of the ITS rDNA and TEF- $1 \alpha$ sequences. Thus, it could represent another cryptic species in the $N$. parvum $/ \mathrm{N}$. ribis complex. Additional isolates and DNA sequence data for a greater number of gene regions will be required to resolve its identity. Pathogenicity tests in this study showed that the isolate has the ability to produce lesions on Eucalyptus trees, which were generally longer than those produced by $F$. fabicercianum.

Two Lasiodiplodia species, L. pseudotheobromae and L. theobromae, were identified in this study. The latter species is a widely distributed plant pathogen that has most commonly been reported from the tropics and subtropics (Punithalingam, 1980). It has been associated with more than 500 host plants including Eucalyptus (Punithalingam, 1976; Roux et al., 2000, 2001; Burgess et al., 2006; Mohali et al., 2007). This pathogen has been reported from Eucalyptus trees in Africa (Roux et al., 2000, 2001), Australia (Burgess et al., 2006) and South America (Mohali et al., 2007), and is considered the most aggressive species of Botryosphaeriaceae on these trees (Pavlic et al., 2007; Mohali et al., 2009). In the current study, L. theobromae was second only to L. pseudotheobromae in terms of its pathogenicity, which further supports the view that $L$. theobromae is one of the most damaging species of Botryosphaeriaceae on Eucalyptus (Slippers \& Wingfield, 2007).

Lasiodiplodia pseudotheobromae is a sister species to L. theobromae and was recently described from species of Acacia, Citrus, Coffea, Gmelina and Rosa (Alves et al., 2008). It has also been 
identified on Eucalyptus spp. in eastern Australia (Mohali et al., 2005; Alves et al., 2008; Slippers et al., 2009) and Venezuela (Mohali et al., 2005; Alves et al., 2008; Slippers et al., 2009). In this study, isolates of this species were the most aggressive of all the Botryosphaeriaceae tested. Previous inoculations on Terminalia trees also showed that L. pseudotheobromae is the most pathogenic among all the tested species of Botryosphaeriaceae on those trees (Begoude et al., 2010a).

Overall results of this study suggest that it is important to consider the impact of genotype by isolate and environment interaction when conducting artificial screening trials. For example, in the field pathogenicity trial on Eucalyptus genotypes CEPT-3, CEPT-4 and CEPT-5, lesions produced by isolate CMW 24702 of $L$. theobromae were significantly longer than those of $N$. parvum and the controls. In contrast, lesions produced by L. theobromae on Eucalyptus clones in Venezuela were significantly shorter than those of $N$. parvum, while the lesions produced by L. theobromae and the controls were not significantly different (Mohali et al., 2009). It is thus important to select the appropriate isolates for screening trials and to consider the involvement of isolate by tree genotype interaction, which has also been shown to be important for the Eucalyptus stem pathogen Chrysoporthe austroafricana (Van Heerden et al., 2005; Gryzenhout et al., 2009).

Species of Botryosphaeriaceae are considered to be a significant threat to the production and sustainability of Eucalyptus plantations. These fungi can infect native and introduced or cultivated hosts and appear to have been moved easily between different countries and continents (Slippers \& Wingfield, 2007; Slippers et al., 2009). The results of this study provide a foundation for future work aimed at managing diseases caused by the Botryosphaeriaceae in Eucalyptus plantations in China.

\section{Acknowledgements}

This study was initiated as part of a bilateral agreement between South Africa and China, and funded through the projects of 30771732, 2007DFA31190 and 2006BAD08A11. We thank the members of the Tree Protection Co-operative Programme (TPCP) for financial support. We are also grateful to Professor Hennie Groeneveld and Dr Mike van der Linde for providing the statistical analyses, Dr Hugh Glen for the Latin description, and colleagues of LeiZhou Forestry Bureau, XinTao Mou, GuiXiang Zhao and ChunYan Xie for their valuable assistance in the field.

\section{References}

Alves A, Crous PW, Correia A, Phillips AJL, 2008. Morphological and molecular data reveal cryptic speciation in Lasiodiplodia theobromae. Fungal Diversity 28, 1-13.

Barber P, Burgess T, Hardy GJ, Slippers B, Wingfield MJ, 2005. Morphology and DNA sequence comparisons show that well defined species of Botryosphaeria from Eucalyptus in Australia have Dichomera-like anamorphs. Mycological Research 109, 1347-63.

Barr ME, 1987. Prodromus to Class Loculoascomycetes. Amherst, MA, USA: Hamilton I. Newell, Inc.

Begoude BAD, Slippers B,Wingfield MJ, Roux J, 2010a. The pathogenic potential of endophytic Botryosphaeriaceous fungi on Terminalia species in Cameroon. Forest Pathology. doi:10.1111/j.1439-0329.2010.00671.x (in press). 
Begoude BAD, Slippers B,Wingfield MJ, Roux J, 2010b. Botryosphaeriaceae associated with Terminalia catappa in Cameroon, South Africa and Madagascar. Mycological Progress 9, 101-23.

Burgess TI, Barber PA, Hardy GEStJ, 2005. Botryosphaeria spp. associated with eucalypts in Western Australia, including the description of Fusicoccum macroclavatum sp. nov. Australasian Plant Pathology 34, 557-67.

Burgess TI, Barber PA, Mohali S, Pegg G, De Beer ZW, Wingfield MJ, 2006. Three new Lasiodiplodia spp. from the tropics, recognised based on DNA sequence comparisons and morphology. Mycologia 98, 423-35.

Carbone I, Anderson JB, Kohn LM, 1999. A method for designing primer sets for speciation studies in filamentous ascomycetes. Mycologia 3, 553-6.

Crous PW, Slippers B, Wingfield MJ et al., 2006. Phylogenetic lineages in the Botryosphaeriaceae. Studies in Mycology 55, 235-53.

Farris JS, Kallersjo M, Kluge AG, Bult C, 1995. Testing significance of incongruence. Cladistics 10, 315-9.

Felsenstein J, 1985. Confidence intervals on phylogenetics: an approach using bootstrap. Evolution 39, 783-91.

Gezahgne A, Roux J, Slippers B, Wingfield MJ, 2004. Identification of the causal agent of Botryosphaeria stem canker in Ethiopian Eucalyptus plantations. South African Journal of Botany 70, 241-8.

Gryzenhout M, Wingfield BD, Wingfield MJ, 2009. Taxonomy, Phylogeny, and Ecology of Barkinhabiting and Tree-pathogenic Fungi in the Cryphonectriaceae. Minnesota, USA: APS Press.

Huelsenbeck JP, Bull JJ, Cunningham CW, 1996. Combining data in phylogenetic analysis. Trends in Ecology \& Evolution 11, 152-8.

Iglesias-Trabad G, Wilstermann D, 2008. Eucalyptus universalis. Global cultivated eucalypt forest map 2008 Version 1.0.1 in GIT Forestry Consulting's EUCALYPTOLOGICS: Information resources on Eucalyptus cultivation worldwide. Retrieved from http://www.git-forestry.com (29 March 2009).

Jacobs K, Bergdahl DR, Wingfield MJ et al., 2004. Leptographium wingfieldii introduced into North America and found associated with exotic Tomicus piniperda and native bark beetles. Mycological Research 108, 411-8.

Katoh K, Misawa K, Kuma K, Miyata T, 2002. MAFFT: a novel method for rapid multiple sequence alignment based on fast Fourier transform. Nucleic Acids Research 30, 3059-66.

Mehl JWM, Slippers B, Roux J, Wingfield MJ, 2010. Botryosphaeriaceae associated with Pterocarpus angolensis (kiaat) in South Africa. Mycologia doi: 10.3852/10-003 (in press).

Mohali S, Burgess TI, Wingfield MJ, 2005. Diversity and host association of the tropical tree endophyte Lasiodiplodia theobromae revealed using SSR markers. Forest Pathology 35, 385-96. 
Mohali S, Slippers B, Wingfield MJ, 2007. Identification of Botryosphaeriaceae species from Eucalyptus, Acacia and Pinus in Venezuela. Fungal Diversity 25, 143-65.

Mohali S, Slippers B, Wingfield MJ, 2009. Pathogenicity of seven species of the Botryosphaeriaceae on Eucalyptus clones in Venezuela. Australasian Plant Pathology 38, 135-40.

Nylander JAA, 2004. MrModeltest 2.3. Program distributed by the author. Uppsala University, Sweden: Evolutionary Biology Centre.

Pavlic D, Slippers B, Coutinho TA, Wingfield MJ, 2007. Botryosphaeriaceae occurring on native Syzygium cordatum in South Africa and their potential threat to Eucalyptus. Plant Pathology 56, 624-36.

Pavlic D, Wingfield MJ, Barber P, Slippers B, Hardy GEStJ, Burgess TI, 2008. Seven new species of the Botryosphaeriaceae from baobab and other native trees in Western Australia. Mycologia 100, 851-66.

Pavlic D, Slippers B, Coutinho TA,Wingfield MJ, 2009a. Multiple gene genealogies and phenotypic data reveal cryptic species of the Botryosphaeriaceae: a case study on the Neofusicoccum parvum $N$. ribis complex. Molecular Phylogenetics and Evolution 51, 259-68.

Pavlic D, Slippers B, Coutinho TA, Wingfield MJ, 2009b. Molecular and phenotypic characterization of three phylogenetic species discovered within the Neofusicoccum parvum $N$. ribis complex. Mycologia 5, 636-47.

Phillips AJL, Oudemans PV, Correia A, Alves A, 2006. Characterisation and epitypification of Botryosphaeria corticis, the cause of blueberry cane canker. Fungal Diversity 21, 141-55.

Punithalingam E, 1976. Botryodiplodia theobromae. Kew, UK: Commonwealth Mycological Institute: CMI Descriptions of Pathogenic Fungi and Bacteria no. 519.

Punithalingam E, 1980. Plant diseases attributed to Botryodiplodia theobromae Pat. Kew, UK: Commonwealth Mycological Institute.

Raeder U, Broda P, 1985. Rapid preparation of DNA from filamentous fungi. Letters in Applied Microbiology 1, 17-20.

Rodas CA, Slippers B, Gryzenhout M, Wingfield MJ, 2009. Botryosphaeriaceae associated with Eucalyptus canker diseases in Colombia. Forest Pathology 39, 110-23.

Ronquist F, Huelsenbeck JP, 2003. MrBayes 3: Bayesian phylogenetic inference under mixed models. Bioinformatics 19, 1572-4.

Roux J, Coutinho TA, Wingfield MJ, Bouillet J-P, 2000. Diseases of plantation Eucalyptus in the Republic of Congo. South Africa Journal of Science 96, 454-6.

Roux J, Coutinho TA, Mujuni Byabashaija D, Wingfield MJ, 2001. Diseases of plantation Eucalyptus in Uganda. South African Journal of Science 97, 16-8.

SAS Institute Inc., 1999. SAS/STAT Users Guide. Version 8. Cary, NC, USA: SAS Institute Inc. 
Slippers B, Wingfield MJ, 2007. Botryosphaeriaceae as endophytes and latent pathogens of woody plants: diversity, ecology and impact. Fungal Biology Reviews 21, 90-106.

Slippers B, Crous PW, Denman S, Coutinho TA, Wingfield BD, Wingfield MJ, 2004a. Combined multiple gene genealogies and phenotypic characters differentiate several species previously identified as Botryosphaeria dothidea. Mycologia 96, 83-101.

Slippers B, Fourie G, Crous PW et al., 2004b. Species and distribution of Botryosphaeria spp. on native and introduced Eucalyptus trees in South Africa and Australia. Studies in Mycology 50, 34358 .

Slippers B, Burgess T, Pavlic D et al., 2009. A diverse assemblage of Botryosphaeriaceae infect Eucalyptus in native and non-native environments. Southern Forests 71, 101-10.

Smith H, Kemp GHJ,WingfieldMJ, 1994. Canker and die-back of Eucalyptus in South Africa caused by Botryosphaeria dothidea. Plant Pathology 43, 1031-4.

Smith H,WingfieldMJ, Petrini O, 1996. Botryosphaeria dothidea endophytic in Eucalyptus grandis and Eucalyptus nitens in South Africa. Forest Ecology and Management 89, 189-95.

Smith H, Crous PW, Wingfield MJ, Coutinho TA, Wingfield BD, 2001. Botryosphaeria eucalyptorum sp. nov., a new species in the B. dothidea-complex on Eucalyptus in South Africa. Mycologia 93, 277-85.

Swofford DL, 2002. PAUP*. Phylogenetic Analysis Using Parsimony (*and other methods). Version 4.0b10. Sunderland, MA, USA: Sinauer Associates.

Tamura K, Dudley J, Nei M, Kumar S, 2007. MEGA4: Molecular Evolutionary Genetics Analysis (MEGA) software version 4.0. Molecular Biology and Evolution 24, 1596-9.

Van Heerden SW, AmersonHV, Preisig O, Wingfield BD, Wingfield MJ, 2005. Relative pathogenicity of Cryphonectria cubensis on Eucalyptus clones differing in the tolerance to $C$. cubensis. Plant Disease 89, 659-62.

White TJ, Bruns T, Lee S, Taylor J, 1990. Amplification and direct sequencing of fungal ribosomal RNA genes for phylogenetics. In: Innis MA, Gelfand DH, Snisky JJ, White TJ, eds. PCR Protocols: a Guide to Methods and Applications. San Diego, CA, USA: Academic Press, 315-22.

Wingfield MJ, Slippers B, Hurley BP, Coutinho TA, Wingfield BD, Roux J, 2008. Eucalypt pests and diseases: growing threats to plantations productivity. Southern Forests 70, 139-44.

Xie YJ, 2006. Eucalypt Research at the Beginning of 21st Century. China: China Forestry House Press. (in Chinese).

Zhou XD, Xie YJ, Chen SF, Wingfield MJ, 2008. Diseases of eucalypt plantations in China: challenges and opportunities. Fungal Diversity 32, 1-7. 